\title{
Factors influencing the occurrence and distribution of Corbicula fluminea (Müller, 1774) in the River Lima estuary
}

\author{
R. Sousa ${ }^{1,2^{*}}$, C. Antunes ${ }^{1,3}$, L. Guilhermino ${ }^{1,2}$ \\ ${ }_{1}^{1}$ CIIMAR - Centro Interdisciplinar de Investigação Marinha e Ambiental, Rua dos Bragas 289, 4050-123 Porto, Portugal. \\ 2 ICBAS - Instituto de Ciências Biomédicas de Abel Salazar, Universidade do Porto, Departamento de Estudos de Populações, Laboratório de \\ Ecotoxicologia, Lg. Prof. Abel Salazar 2, 4099-003 Porto, Portugal. \\ 3 Aquamuseu do Rio Minho - Parque do Castelinho, 4920-290 Vila Nova de Cerveira, Portugal.
}

\begin{abstract}
This study evaluated the status of the Asian clam Corbicula fluminea (Müller, 1774) in the River Lima estuary (Portugal), which it first invaded in 2002. During the summers of 2004 and 2005, spatial and temporal variations in the abundance, biomass and population structure of $C$. fluminea were investigated in this estuary. This species was present in a limited intertidal area of the estuary and was rarely found in the subtidal zone. Its abundance and biomass were considerably lower than those found in other estuarine systems. Based on these studies it appears that salinity fluctuations and possibly other factors such as nutrients and environmental contaminants are keeping this invasive species from reaching its full potential. Given the lower abundance and biomass recorded and the restrict distribution of the species in this estuary, the eradication of this nonindigenous invasive species is still possible. The findings of this study may be useful for the management of this species not only in the River Lima estuary but also in other locations it may invade.
\end{abstract}

Keywords : Lima estuary, Corbicula fluminea, nonindigenous invasive species, population structure.

\section{Introduction}

The introduction of nonindigenous invasive species (NIS) has been recognized as a critical environmental problem since the pioneering studies of Elton (1958). The introduction and further dispersion of NIS may produce considerable ecological, genetic, economical and social impacts (Carlton \& Geller 1993, Lodge 1993, Cohen \& Carlton 1998, Kolar \& Lodge 2001, Grosholz 2002). These species can function as introductory vectors of diseases, may change the ecosystem, reduce biodiversity and cause great economic damage (Vitousek et al. 1996, Mack et al. 2000, Pimentel et al. 2000). Therefore, the control and management of NIS is a priority issue and will be a great challenge for conservation biology in the next decades.

According to Allendorf \& Lundquist (2003), two primary steps in the evolution of invasive populations in new habitats exist. The first one is the introduction, colonization and establishment of the species in the new habitat. The second step deals with the dispersion and the subsequent replacement of the native species by the introduced species. Between these steps emerge the lag time phase, when several species recently esta- blished persist with low or even undetectable densities in a fixed area for a variable period of time, before entering into an exponential growth phase where the population rapidly invades the new environment (Shigesada \& Kawasaki 1997, Crooks \& Soulé 1999, Crooks 2005). This lag time period may have the duration of months, years or even decades (Sakai et al. 2001).

The Asian clam Corbicula fluminea (Müller, 1774) is one of the most invasive bivalves in freshwater ecosystems (Phelps 1994, Cataldo \& Boltovskoy 1999, Hakenkamp \& Palmer 1999, Darrigran 2002, McMahon 2002). This species, with origin in Asiatic ecosystems, has been dispersing worldwide over the last 80 years. In the beginning of the last century, $C$. fluminea colonized North America and in the 1980s its presence was reported in Europe for the first time (Mouthon 1981, Araujo et al. 1993, McMahon 1999). Given the potential impacts at both ecological and economical levels that the introduction of $C$. fluminea may cause, it is essential to derive demographic models describing its dispersion and population dynamics in new environments. These models may be of considerable help in the adoption of mitigation measures and other ma-

* Corresponding author : E-mail: ronaldo.sousa@ ciimar.up.pt

Article available at http://www.limnology-journal.org or http://dx.doi.org/10.1051/limn/2006017 
nagement actions that may be required (Phelps 1994, Darrigran 2002, McMahon 2002).

The invasion of a new environment by the NIS, if studied from its beginning, provides a considerable amount of data that may be useful in dealing with future invasions in other ecosystems. The River Lima estuary, in the North of Portugal, was recently invaded by C. fluminea (Sousa et al. 2006). Its presence was noticed for the first time in 2002 and since then, the occurrence of the species has been constant but at low densities. The main objective of this study was to describe C. fluminea spatial and temporal distribution in the River Lima estuary in the last two years (with a small reference to its first occurrence in 2002). The pattern of distribution and the evolution of the population in this first phase of new habitat invasion may be useful to predict its possible expansion in the ecosystem and to support management measures for the mitigation of the impacts caused by this invasion. In addition, the study of this phase also generates data that may be useful for the management of future invasions in similar environments.

\section{Material and Methods}

\section{Study area}

The hydrological basin of the River Lima has an area of about $2480 \mathrm{~km}^{2}, 1303 \mathrm{~km}^{2}$ in Spain (53\%) and 1 $177 \mathrm{~km}^{2}$ in Portugal (47\%). The estuary is located in the NW of Portugal (Fig. 1) and the influence of spring

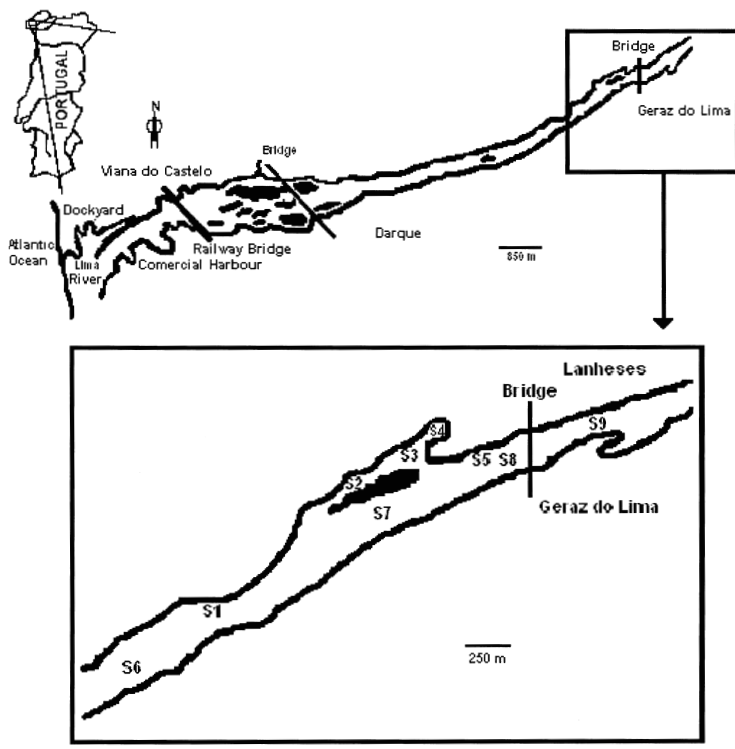

Fig. 1. Map of the Lima estuary showing the nine sampling stations. tides extends approximately $20 \mathrm{~km}$ upstream. A more detailed description of its physical and chemical characteristics and its benthic organisms is given by Sousa et al. (2006). The studied area was focused in the upper estuarine sector of the River Lima which is known to be colonized by $C$. fluminea at least since 2002 (Sousa et al. 2006). This area includes subtidal and intertidal areas along no more than $2 \mathrm{~km}$ of the river course. In several preliminary studies performed in upstream and downstream areas, $C$. fluminea was never found. Therefore, the study was restricted to the area known as being colonized by this species.

\section{Sampling and Data analysis}

Samples were collected in August 2004 and 2005 in both subtidal and intertidal areas of the Lima estuary, at low tide (Fig. 1). Ten replicates per sampling station were gathered by a Van Veen grab with an area of 500 $\mathrm{cm}^{2}$. Stations 1, 2, 3, 4 and 5 were located in intertidal areas and the stations 6, 7, 8 and 9 in subtidal areas.

During fieldwork, the following water column parameters were determined: temperature, salinity, dissolved oxygen and $\mathrm{pH}$. In intertidal areas, they were measured in adjacent low water pools and in the subtidal areas they were determined close to the bottom. This information was gathered using a multiparametrical sea gauge YSI 6820. Particle size and organic matter content of the sediment from each site were also determined. Sediment granulometry was assessed after a drying period of $72 \mathrm{~h}$ at $60^{\circ} \mathrm{C}$ in an oven. Dried sediment was sieved through a column of sieves corresponding to integer values of the Wentworth scale and the frequency of each class was expressed as the percentage of total weight. The amount of organic matter in the sediment was determined after a $24 \mathrm{~h}$ combustion period, at $550^{\circ} \mathrm{C}$, in a muffle furnace.

The $C$. fluminea individuals present in the samples were collected using a sieve with a mesh size of $1 \mathrm{~mm}$. Specimens were immediately separated, sorted and preserved. Subsequently, they were enumerated and their shell length was measured with a digital caliper. Faunal biomass was calculated by the Ash Free Dry Weight (AFDW) method (Kramer et al., 1994) and the relationship between total length and biomass (AFDW) was also estimated for 40 individuals (20 individuals from which year, data pooled). The relationship between total length and biomass AFDW was given by the following equation:

Biomass $(\mathrm{g}$ AFDW $)=3 \mathrm{E}-05 *$ Shell Length $(\mathrm{mm})^{2,8353}$ $\left(\mathrm{N}=40, \mathrm{R}^{2}=0.95\right)$ 
For population structure analysis, clams were included in $2 \mathrm{~mm}$ class intervals according to their shell length. This approach allows the detection of recent recruitments.

Finally, an environmental variable versus sampling station matrix was analysed using Principal Components Analysis (PCA) for grouping sampling stations in relation to environmental factors. This analysis was performed using the PRIMER package (Clarke \& Warwick 2001).

\section{Results}

In general, there were no great spatial or temporal variations in the environmental parameters measured in the water column and in the sediment compartment (Table 1). However, the values of temperature and sali-

Table. 1. Physical and chemical parameters of water and sediments at the nine sampling stations in the years 2004 and 2005: temperature $\left(\mathrm{T}^{\circ}{ }^{\circ} \mathrm{C}\right)$, salinity (S-psu), dissolved oxygen (DO- $\mathrm{mg} \mathrm{1-1}$ ), $\mathrm{pH}$, gravel (G-\%), very coarse sand (VCS-\%), coarse sand (CS-\%), medium sand (MS-\%), fine sand (FS-\%), very fine sand (VFS-\%), silt+clay $(\mathrm{S}+\mathrm{C}-\%)$, and organic matter $(\mathrm{OM}-\%)$.

\begin{tabular}{|c|c|c|c|c|c|c|c|c|c|c|c|c|}
\hline Station & $\begin{array}{c}\mathrm{T} \\
\left({ }^{\circ} \mathrm{C}\right)\end{array}$ & $\begin{array}{c}\mathrm{S} \\
(\mathrm{psu})\end{array}$ & $\begin{array}{c}\mathrm{DO} \\
\left(\mathrm{mg} \mathrm{l}^{-1}\right)\end{array}$ & $\mathrm{pH}$ & $\begin{array}{c}\mathrm{G} \\
(\%)\end{array}$ & $\begin{array}{l}\begin{array}{l}\text { VCS } \\
(\%)\end{array} \\
\end{array}$ & $\begin{array}{l}\text { CS } \\
(\%)\end{array}$ & $\begin{array}{l}\text { MS } \\
(\%)\end{array}$ & $\begin{array}{l}\text { FS } \\
(\%)\end{array}$ & $\begin{array}{l}\text { VFS } \\
(\%)\end{array}$ & $\begin{array}{l}\begin{array}{l}\mathrm{S}+\mathrm{C} \\
(\%)\end{array} \\
(\%)\end{array}$ & $\begin{array}{l}\mathrm{OM} \\
(\%)\end{array}$ \\
\hline $\begin{array}{l}\text { S1/04 } \\
\end{array}$ & 20.78 & 0.71 & 7.91 & 7.81 & 43.39 & 25.82 & 15.31 & 10.07 & 3.91 & 1.28 & 0.23 & 1.98 \\
\hline S2/04 & 20.13 & 0.74 & 8.11 & 8.72 & 10.14 & 22.67 & 25.92 & 14.08 & 13.11 & 10.70 & 3.39 & 6.05 \\
\hline S3/04 & 20.86 & 0.67 & 7.68 & 8.84 & 8.35 & 17.38 & 27.84 & 22.18 & 10.37 & 9.79 & 4.08 & 5.01 \\
\hline S $4 / 04$ & 20.38 & 0.70 & 8.42 & 8.73 & 6.38 & 15.33 & 20.40 & 23.83 & 15.19 & 9.58 & 9.30 & 6.71 \\
\hline S5/04 & 20.21 & 0.68 & 7.74 & 8.00 & 35.68 & 21.59 & 19.75 & 18.43 & 4.13 & 0.38 & 0.04 & 1.49 \\
\hline S6/04 & 20.53 & 1.20 & 7.89 & 7.98 & 32.08 & 33.75 & 23.15 & 8.73 & 1.63 & 0.53 & 0.12 & 0.92 \\
\hline S7/04 & 20.75 & 1.14 & 7.58 & 8.12 & 52.89 & 21.49 & 17.80 & 6.38 & 1.26 & 0.15 & 0.03 & 0.69 \\
\hline S8/04 & 20.58 & 0.65 & 8.01 & 8.26 & 37.51 & 24.39 & 22.99 & 13.08 & 1.78 & 0.22 & 0.04 & 0.71 \\
\hline S9/04 & 20.49 & 0.41 & 7.95 & 8.19 & 45.29 & 22.39 & 19.17 & 10.32 & 2.42 & 0.33 & 0.08 & 0.99 \\
\hline $\mathrm{S} 1 / 05$ & 22.65 & 3.14 & 8.01 & 7.63 & 43.82 & 26.81 & 14.82 & 9.75 & 3.79 & 0.79 & 0.22 & 1.90 \\
\hline $\mathrm{S} 2 / 05$ & 22.44 & 1.79 & 7.89 & 8.14 & 10.98 & 25.07 & 23.07 & 14.33 & 14.00 & 10.42 & 2.12 & 5.87 \\
\hline $\mathrm{S} 3 / 05$ & 22.86 & 2.69 & 7.52 & 8.84 & 9.52 & 17.86 & 30.91 & 22.85 & 9.50 & 7.01 & 2.35 & 4.76 \\
\hline $\mathrm{S} 4 / 05$ & 22.54 & 1.95 & 7.89 & 8.81 & 5.21 & 15.45 & 21.77 & 23.92 & 16.80 & 9.36 & 7.49 & 6.52 \\
\hline S5/05 & 22.38 & 1.80 & 8.42 & 8.73 & 33.00 & 22.30 & 21.03 & 20.26 & 3.01 & 0.37 & 0.04 & 1.71 \\
\hline S6/05 & 21.53 & 10.52 & 7.75 & 7.13 & 33.41 & 30.86 & 24.43 & 9.61 & 1.09 & 0.49 & 0.11 & 0.80 \\
\hline S7/05 & 22.75 & 12.06 & 7.74 & 7.29 & 48.40 & 22.82 & 18.24 & 9.51 & 0.81 & 0.19 & 0.04 & 0.74 \\
\hline S8/05 & 22.49 & 1.58 & 7.89 & 7.63 & 34.55 & 26.30 & 23.56 & 12.76 & 2.47 & 0.29 & 0.07 & 0.76 \\
\hline S9/05 & 21.18 & 0.57 & 7.65 & 7.70 & 41.29 & 23.60 & 22.42 & 10.63 & 1.42 & 0.50 & 0.14 & 1.11 \\
\hline
\end{tabular}

nity increased from 2004 to 2005 . Water temperature ranged from $20.1{ }^{\circ} \mathrm{C}$ (station 2 in 2004) to $22.9^{\circ} \mathrm{C}$ (station 3 in 2005), and the salinity from 0.4 psu (station 9 in 2004) to 12.1 psu (station 7 in 2005). Water dissolved oxygen values varied between $7.5 \mathrm{mg} \mathrm{l}^{-1}$ (station 3 in 2005) and $8.4 \mathrm{mg} \mathrm{l}^{-1}$ (station 5 in 2005), while $\mathrm{pH}$ ranged from 7.1 (station 6 in 2005) to 8.8 (station 3 in 2005). Sediment analysis revealed a substratum with coarser sediment with a preponderance of sands.

PCA matrices of environmental factors versus sampling stations (Fig. 2) revealed a clear pattern over the sampling stations. From the projection against the first axis of variability, stations appeared distributed along a physical and chemical gradient, with the stations having finer sediments and high organic matter (stations

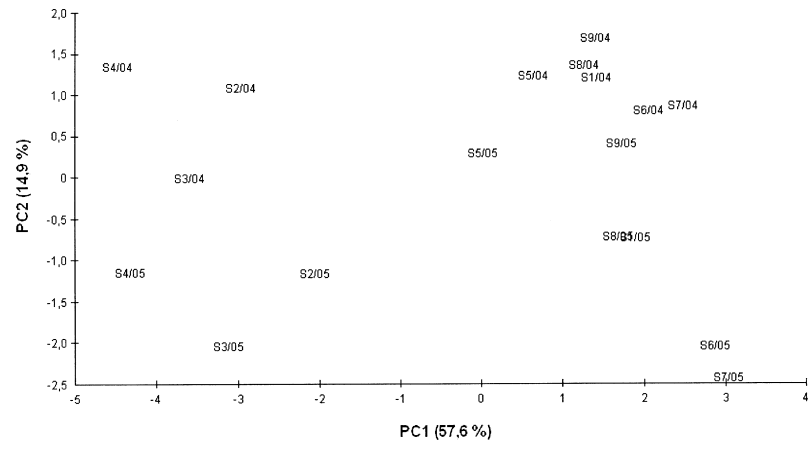

Fig. 2. Analysis of physical and chemical factors of water column and sediment from PCA of factors $\mathrm{x}$ station matrices for the years 2004 and 2005 . The percentages of variability explained by the two principal axes are shown.

2, 3 and 4) along one edge and the stations with coarser sediments and low organic matter located on the other. Along the second axis of variability, the separation of the stations was related to the environmental factors measured in the water column principally salinity, $\mathrm{pH}$ and dissolved oxygen.

Abundance and biomass showed variations along the intertidal (with the exception of station 5) and subtidal sampling stations, with higher abundances and biomass values in the intertidal sites. However, these values did not differ greatly between years. Mean abundance per station ranged from 0 individuals per $\mathrm{m}^{2}$ at station 5 in 2005, and stations 6,8 and 9 in both years to 60 individuals per $\mathrm{m}^{2}$ at station 4 in 2004 (Fig. 3).

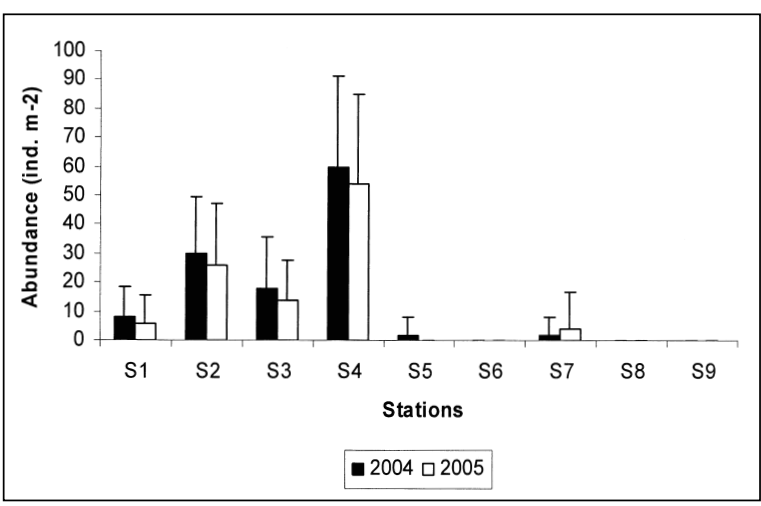

Fig. 3. Mean abundance of Corbicula fluminea (+SD) throughout the nine sampling stations in the years 2004 and 2005.

Total mean abundances were 13.3 and 11.6 individuals per $\mathrm{m}^{2}$ in 2004 and 2005, respectively. Mean biomass ranged from $0 \mathrm{~g}$ AFDW per $\mathrm{m}^{2}$ at station 5 in 2005, and stations 6,8 and 9 in both years to $23.78 \mathrm{~g}$ AFDW per $\mathrm{m}^{2}$ at station 4 in 2005 (Fig. 4). Total mean biomass 


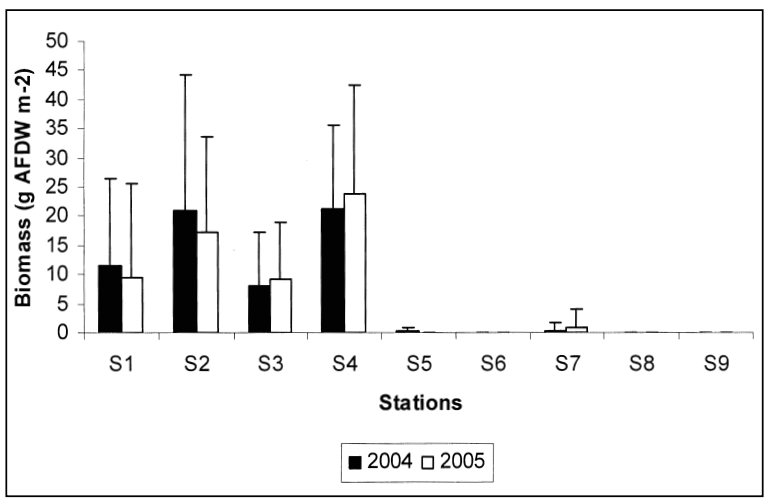

Fig. 4. Mean biomass of Corbicula fluminea (+SD) throughout the nine sampling stations in the years 2004 and 2005.

was 6.89 and $6.74 \mathrm{~g}$ AFDW per $\mathrm{m}^{2}$ in 2004 and 2005, respectively.

The $C$. fluminea population structure (subtidal and intertidal data pooled) in 2004 is similar to that found in 2005 (Fig. 5). However, in 2005 more individuals with higher shell lengths were recorded and only a few small specimens were found. During the study period, the maximum shell length value was found at station 1 $(51.6 \mathrm{~mm})$ and the minimum was recorded at station 2 $(13.0 \mathrm{~mm})$, both in 2005 .

\section{Discussion}

In the present study, differences in temperature and salinity values were found between 2004 and 2005. The values of these two abiotic factors determined in 2005 were higher than those recorded in 2004. Perhaps, this was a reflection of the severe drought that occurred in 2005, which increased salinity values upstream. The year 2005 was a hot year. Therefore, at- mospheric temperatures may have contributed to the higher water temperatures in 2005 compared to 2004. Spatial fluctuations of water dissolved oxygen and $\mathrm{pH}$ values were never large which was in good agreement with results gathered in 2002 (Sousa et al. 2006). The comparison of subtidal sediment characteristics determined in the present study with those reported by Alves (1996) and Sousa (2003) indicates that no significant changes occurred in recent years, and the sediments were predominantly sands. Cumulative curves of the sediment along the nine sites are very similar (data not shown); however, finer sediments were more abundant at stations 2, 3 and 4 than at the others. These stations with finer sediments and high organic matter content correspond to the sites with higher $C$. fluminea abundances and biomasses.

C. fluminea has all the characteristics of an r-selected species, with elevated growth and fecundity and extensive capacity of dispersion that allows rapid population recovery, which is fundamental for invasion success. Once established, this species may have considerable negative ecological, environmental and economical impacts (Phelps 1994, Hakenkamp \& Palmer 1999, Hakenkamp et al. 2001, McMahon 2002). This NIS was recorded for the first time in the River Lima estuary in 2002 (Sousa et al. 2006). This study was only performed in the subtidal area, and C. fluminea was only found in one sampling station located in the upper estuary (near station 7 of the present study). Since then, this species has been found in the estuary but with low abundances and this study shows that $C$. flumine $a$ abundance and biomass did not have great oscillations during 2004 and 2005. However, C. fluminea abundance and biomass in this estuarine ecosystem were very low compared to those found, for example, in the River Minho estuary, an adjacent estuarine area

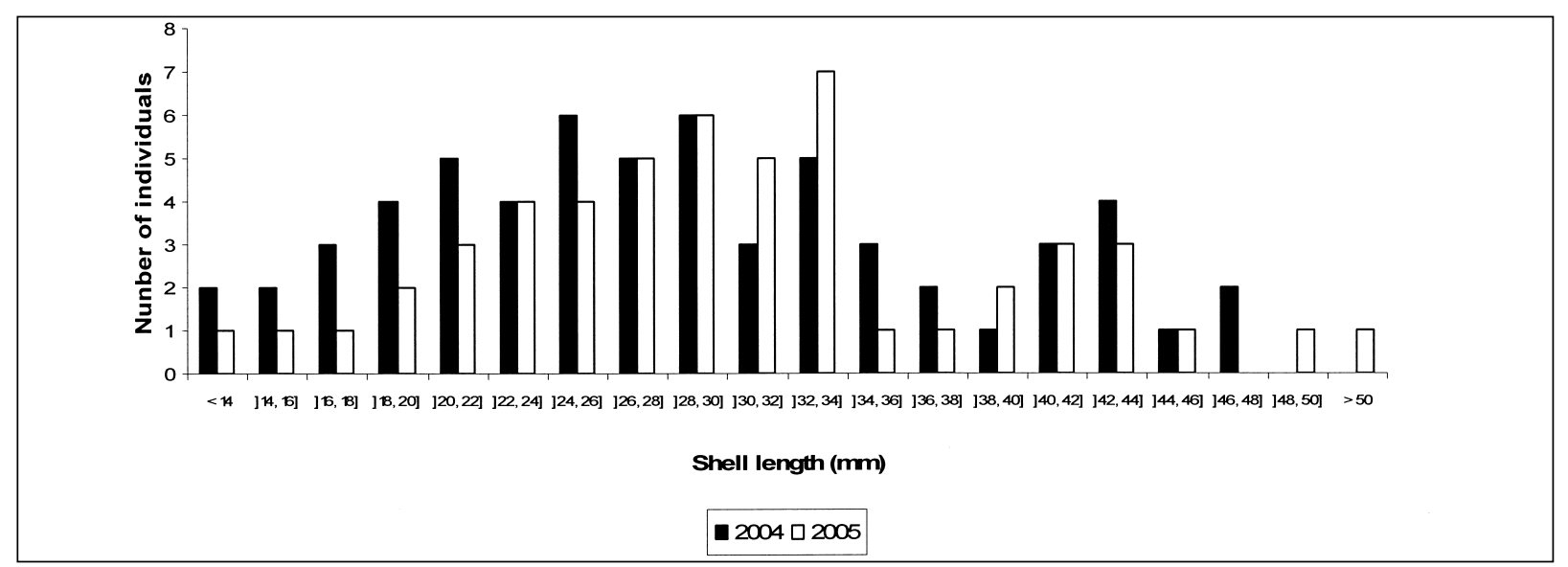

Fig. 5. Length profiles of Corbicula fluminea in the River Lima estuary, 2004 and 2005. 
with similar hydrological and geological characteristics and also colonized by this NIS. The presence of $C$. fluminea in the River Minho estuary has been recognized since 1989 (Araujo et al. 1993). The population has been increasing since then, and presently shows a considerable abundance, biomass and distribution (Sousa et al. 2005). In the River Minho estuary, C. fluminea is dispersed for more than $30 \mathrm{~km}$, with mean values of abundance and biomass of 1253 individuals per $\mathrm{m}^{2}$ and $95.2 \mathrm{~g} \mathrm{AFDW}$ per $\mathrm{m}^{2}$, respectively (Sousa et al. 2005). A model based on a stepwise multiple regression combining several abiotic factors in order to determine $C$. fluminea biomass distribution was applied in the freshwater subtidal area of the River Minho estuary. This model explained almost $60 \%$ of the variation in C. fluminea biomass $\left(\mathrm{R}^{2}=59.3 \%, \mathrm{~F}_{[9,86]}=13.9, \mathrm{p}<0.001\right)$ and showed that red-ox potential, organic matter, hardness, very coarse sand and fine sand showed a positive coefficient, thus bivalve biomass was greater for higher values of these variables, whereas with nitrates and ammonia, a negative relationship was observed (Sousa et al. submitted). Given the great environmental similarities between these two adjacent Portuguese estuaries we expected a higher invasive behaviour in the Lima estuary. Additionally, C. fluminea also reached high abundances in other European and North and South American freshwater ecosystems (Phelps 1994, Cataldo \& Boltovskoy 1999, Hakenkamp \& Palmer 1999, Hakenkamp et al. 2001, Darrigran 2002, Mouthon 2001a, b, 2003, McMahon 2002, Mouthon \& Parghentanian 2004).

A possible explanation for the low abundances, biomasses and the apparent range expansion stagnation showed by the $C$. fluminea population in the River Lima estuary is the more recent introduction of the species in this ecosystem. In the literature, there are several examples of nonindigenous plants and animals recently established in an ecosystem that persist at low densities for some time (months, years or even decades) before entering an exponential growth phase where they show a high invasive potential (Sakai et al. 2001, Crooks 2005). This period of apparent stagnation is known as the lag time phase (Shigesada \& Kawasaki 1997, Crooks \& Soulé 1999, Crooks 2005) and is characterized by a very slow or inexistent population growth rate (see Byers et al. 2002). In this period, the number of individuals is reduced and the population is facing the challenge of adapting to the new environment.

When we looked at the Lima estuary C. fluminea population structure we did not find individuals with a shell length less than $13 \mathrm{~mm}$. This suggests a deficient recruitment that may be due, for example, to reduced spawning or to a high mortality rate of larvae and/or juveniles. Reduced spawning may result, for example, from a low investment in reproduction due to the necessity of a high energetic investment to face an adverse environment. High mortality of larvae and/or juveniles may be due to inadequate environmental conditions for their survival and development. Both cases will have a negative impact on population growth and may contribute to a lag time phase if they occur in an initial phase of population development. Additionally, environmental conditions seem to have a considerable influence on lag time phase duration (Crooks \& Soulé 1999, Byers et al. 2002 and references therein). C. fluminea has a relatively poor physiologic resistance to abiotic factor variations, including temperature, salinity, emersion, $\mathrm{pH}$, calcium concentration and dissolved oxygen changes (McMahon 2002). Salinity seems to be a major factor influencing the success and velocity of the invasion of new environments by this species in estuarine ecosystems: it is well known that $C$. flumi$n e a$ is very efficacious in colonizing freshwater ecosystems but that it is considerably less efficient in colonizing brackish water environments, even at low salinities values (Morton 1982, 1986). Salinity values in the study area increased in recent years. This factor may be causing difficulties for the adaptation of the species to the new environment and slowing the colonization process. While the species could be well adapted to the other environmental factors, the overriding influence of salinity could be a key factor in limiting the invasive behaviour of the species. Salinity values increased from 2004 to 2005 together with an apparent decrease of $C$. fluminea abundance and biomass. Abundances recorded in subtidal stations, with more pronounced changes in salinity between low and high tide, were lower than in intertidal sites. As well, 2004 and 2005 subtidal abundances were inferior to those found in 2002 when salinity values were considerably lower (Sousa et al. 2006).

Alternative hypotheses for the lower abundances, biomass and failure in dispersal of the Lima estuary $C$. fluminea population are nutrient enrichment, higher values in heavy metals and other environmental contaminants and possible genetic characteristics. We have no data that support the first two hypotheses in the study area but downstream areas are subject to eutrophication processes, heavy metals contamination and dredging activities (Sousa et al. 2006, Sousa et al. in press). In fact, the lower Lima estuary is considerably more contaminated with chemicals resulting from anthropogenic activities than the Minho estuary (Antunes 
et al. unpublished data). Additionally, the $C$. fluminea habitat in the Lima estuary is near a pulp mill with possible contamination. In relation to genetic characteristics, recent studies done by the authors revealed that the $C$. fluminea populations of Minho and Lima estuaries have similar mtCOI sequences (Sousa et al. unpublished data). Furthermore, we have no data that supports a different propagule pressure and the existence of potential predators and/or parasites that controlled the Lima $C$. fluminea population in a different away than for example the Minho estuary population.

The evidence described above suggests that salinity variation, and probably also other environmental factors (e.g. nutrients, environmental contaminants), found in the River Lima estuary are not the most suitable for $C$. fluminea development and may have been hindering population growth and expansion in the ecosystem. However, if the conditions became more favourable and/or the species successfully adapts to the environment, the population may rapidly enter exponential growth and reach the carrying capacity of the ecosystem.

At this moment, the $C$. fluminea population of the River Lima estuary is restricted to a very small area and has a low abundance and biomass. Therefore, this specific phase of population development is the more efficacious period to implement measures to control and reduce the impacts resulting from its introduction since the population is still restricted to a small area and has a low density (Byers et al. 2002). However, one must keep in mind that complete eradication is often difficult and in the case of $C$. fluminea, small juveniles are easily transported by humans and/or aquatic birds which can function as dispersion vectors.

\section{Acknowledgement}

Ronaldo Sousa is supported by a $\mathrm{PhD}$ grant from Portuguese Foundation for Science and Technology - FCT (SFRH/BD/18426/2004) and this work was partially funded by FCT (project RISKA: POCTI/BSE/46225/2002) and European FEDER funds. Special thanks are addressed to Dr. Peter Chapman and Dr. Jonathan Wilson for valuable comments and revision of a previous version of this manuscript. Detailed comments from two anonymous reviewers were also highly appreciated and helped to improve an earlier version of the manuscript.

\section{References}

Allendorf F.W. \& Lundquist L.L. 2003. - Introduction: population, biology, evolution, and control of invasive species. Conserv. Biol., 17, 24-30.

Alves A.M. 1996. - Causas e processos da dinâmica sedimentar na evolução actual do litoral do Alto Minho, Ph.D. thesis, University of Minho, Braga.

Araujo R., Moreno D. \& Ramos M.A. 1993. - The asiatic clam Corbicula fluminea (Müller, 1774) (Bivalvia: Corbiculidae) in Euro- pe. Am. Malacol. Bull., 10, 39-49.

Byers J.E., Reichard S., Randall J.M., Parker I.M., Smith C.S., Lonsdale W.M., Atkinson I.A. E., Seastedt T.R., Williamson M., Chornesky E. \& Hayes D. 2002. - Directing research to reduce the impacts of nonindigenous species. Conserv. Biol., 16, 630-640.

Carlton J.T. \& Geller J.B. 1993. - Ecological roulette: the global transport of nonindigenous marine organisms. Science, 261, 7883

Cataldo D. \& Boltovskoy D. 1999. - Population dynamics of Corbicula fluminea (Bivalvia) in the Paraná river delta (Argentina). $\mathrm{Hy}$ drobiologia, 380, 153-163.

Clarke K.R. \& Warwick R.M. 2001. - Change in Marine Communities: An Approach to Statistical Analysis and Interpretation, $2^{\text {nd }}$ edition. PRIMER-E Ltd, Plymouth Marine Laboratory, Plymouth.

Cohen A.N. \& Carlton J.T. 1998. - Accelerating invasion rate in a highly invaded estuary. Science, 279, 555-558.

Crooks J.A. \& Soulé M.E. 1999. - Lag times in population explosions of invasive species: causes and implications. Pages 103-126 in Invasive Species and Biodiversity Management. Sandlund O. T., Schei P. V. \& Viken A. (eds). Kluwer Academic Publisheres, Dordrecht.

Crooks J. 2005. - Lag times and exotic species: the ecology and management of biological invasions in slow-motion. Ecoscience, 12, 316-329.

Darrigran G. 2002. - Potential impact of filter-feeding invaders on temperate inland freshwater environments. Biol. Invasions., 4, 145-156.

Elton C.S. 1958. - The Ecology of Invasions by Animals and Plants. Methuen, London.

Grosholz E. 2002. - Ecological and evolutionary consequences of coastal invasions. Trends Ecol. Evol., 17, 22-27.

Hakenkamp C.C. \& Palmer M.A. 1999. - Introduced bivalves in freshwater ecosystems: the impact of Corbicula on organic matter dynamics in a sandy stream. Oecologia, 119, 445-451.

Hakenkamp C.C., Ribblett S.G., Palmer M.A., Swan C.M., Reid J.W. \& Goodison M.R. 2001. - The impact of an introduced bivalve (Corbicula fluminea) on the benthos of a sandy stream. Freshwater Biol., 46, 491-501.

Kolar C.S. \& Lodge D.M. 2001. - Progress in invasion biology: predicting invaders. Trends Ecol. Evol., 16, 199-204.

Kramer K.J.M., Brockmann U.H. \& Warwick R.M. 1994. - Tidal Estuaries. Manual of Sampling and Analytical Procedure, A. A. Balkema, Rotterdam.

Lodge D.M. 1993. - Biological invasions: lessons for ecology. Trends Ecol. Evol., 8, 133-137.

Mack R.N., Simberloff D., Lonsdale W.M., Evans H., Clout M. \& Bazzaz F.A. 2000. - Biotic invasions: causes epidemiology, global consequences and control. Ecol. Appl., 10, 689-710.

McMahon R.F. 1999. - Invasive characteristics of the freshwater bivalve Corbicula fluminea. Pages 315-343 in Nonindigenous Freshwater Organisms : Vectors, Biology and Impacts. Claudi R. \& Leach J. (eds). Lewis Publishers, Boca Raton, Florida.

McMahon R.F. 2002. - Evolutionary and physiological adaptations of aquatic invasive animals: $\mathrm{r}$ selection versus resistance. Can. $J$. Fish. Aquat. Sci., 59, 1235-1244.

Morton B. 1982. - Some aspects of the population structure and sexual strategy of Corbicula cf. fluminalis (Bivalvia: Corbiculacea) from the Pearl River, People's Republic of China. J. Mollus. Stud., 48, 1-23.

Morton B. 1986. - Corbicula in Asia - an updated synthesis. Am. Malacol. Bull. Spec. Ed., 2, 113-124.

Mouthon J. 1981. - Sur la présence en France et au Portugal de Corbicula (Bivalvia, Corbiculidae) originaire d'Asie. Basteria, 45, 109-116.

Mouthon J. 2001 a. - Life cycle and population dynamics of the 
Asian clam Corbicula fluminea (Bivalvia: Corbiculidae) in the Rhône River at Creys-Malville (France). Arch. Hydrobiol., 151, 571-589.

Mouthon J. 2001 b. - Life cycle and populations dynamics of the asian clam Corbicula fluminea (Bivalvia: Corbiculidae) in the Saone River at Lyon (France). Hydrobiologia, 452, 109-119.

Mouthon J. 2003. - Longitudinal and temporal variations of density and size structure of Corbicula fluminea (Bivalvia) populations in the Saône and Rhône rivers (France). Ann. Limnol. - Int. J. Lim., $39,15-25$.

Mouthon J. \& Parghentanian T. 2004. - Comparison of the life cycle and population dynamics of two Corbicula species, C. fluminea and $C$. fluminalis (Bivalvia: Corbiculidae) in two French canals. Arch. Hydrobiol., 161, 267-287.

Phelps H.L. 1994. - The Asiatic clam (Corbicula fluminea) invasion and system-level ecological change in the Potomac River Estuary near Washington, D. C. Estuaries, 17, 614-621.

Pimentel D., Lach L., Zuniga R. \& Morrisson D. 2000. - Environmental and economic costs of nonindigenous species in the United States. BioScience, 50, 53-65.

Sakai A.K., Allendorf F.W., Holt J.S., Lodge D.M., Molofsky J., Wi- th K.A., Boughman S., Cabin R.J., Cohen J.E., Ellstrand N.C., McCauley D.E., O'Neil P., Parker I.M., Thompson J.N. \& Weller S.G. 2001. - The population biology of invasive species. Ann. Rev. Ecol. Syst., 32, 305-332.

Shigesada N. \& Kawasaki K. 1997. - Biological Invasions: Theory and Practice. Oxford University Press, Oxford.

Sousa R., 2003. - Estrutura das comunidades de macroinvertebrados bentónicos presentes no estuário do rio Lima, M.Sc. thesis, Univ. Porto, Porto.

Sousa R., Guilhermino L. \& Antunes C. 2005. - Molluscan fauna in the freshwater tidal area of the River Minho estuary, NW of Iberian Peninsula. Ann. Limnol. - Int. J. Lim., 41, 141 - 147.

Sousa R., Dias S. \& Antunes C. 2006. - Spatial subtidal macrobenthic distribution in relation to abiotic conditions in the Lima estuary, NW of Portugal. Hydrobiologia, 559, 135 - 148.

Sousa R., Dias S. \& Antunes C. in press. - Subtidal macrobenthic structure in the lower Lima estuary, NW of Iberian Peninsula. Ann. Zool. Fenn.

Vitousek D.M., D'Antonio C.M., Loope L.L. \& Westbrooks R. 1996. - Biological invasions as global environmental change. Am. Sci., 84, 468-478. 